A $J_{\text {ass }} \mathrm{H}$

Received : 07.03.2018

Revised : 10.05 .2018

Accepted : 24.05.2018

Members of the Research Forum

Associated Authors:

${ }^{1}$ Department of Fruit Crops and Post

Harvest Technology, Horticultural

College and Research Institute,

Periyakulam (T.N.) India
Author for correspondence :

M.I. Manivannan

Department of Horticulture,

Agricultural College and Research

Institute, Killikulam (T.N.) India

Email : mimanivannan@ rediffmail.

com
THEASIAN JOURNALOF HORTICULTURE

Volume 13 | Issue 1 | June, 2018 | 22-24

Visit us -www.researchjournal.co.in
RESEARCH PAPER

DOI : 10.15740/HAS/TAJH/13.1/22-24

\section{Assessment of integrated nutrient management in okra hybrid $\mathrm{CoBh} \mathrm{H} 1$}

\section{M.I. Manivannan and S. Irulandi}

ABSTRACT : An farm trial on integrated nutrient management in okra was undertaken at Krishi Vigyan Kendra, Kanyakumari to find out the combined effect of organic manures, biofertilizers and inorganic fertilizers over the traditional method in Okra hybrid CoBh $\mathrm{H} 1$ on yield, quality parameters and economic feasibility in Kanyakumari district. The trial was conducted during 2016 in five farmers field in a total area of 2 hectares located at Thuckalay block of Kanyakumari district. The assessment of integrated nutrient management was observed in Okra hybrid CoBh H1 with the technology options as recommended by TNAU CPG (2013) and KAU CPG (2011). The traditionally adopted farmers practice i.e., farm yard manure $25 \mathrm{t} / \mathrm{ha}+$ imbalanced use of fertilizer was also included in the trial for assessment. Various yield parameters viz., days to $50 \%$ flowering, number of fruits per plant and yield $(\mathrm{q} / \mathrm{ha})$ and the benefit cost ratio was recorded for the individual farmer. Minimum number of days to flowering (52.0), higher number of fruits per plant (71.8), yield (274.8 q/ha) and cost benefit ratio (3.00) was registered with the technology as suggested by TNAU CPG (2013) wherein maximum number of days to flowering (55.2.0), minimum number of fruits per plant (47.6), yield (230.2 q/ha) and cost benefit ratio (2.78) was recorded with farmers practice.

KEY WORDS : INM, Okra, CoBh H1

HOW TO CITE THIS ARTICLE : Manivannan, M.I. and Irulandi, S. (2018). Assessment of integrated nutrient management in okra hybrid CoBh H1. Asian J. Hort., 13(1) : 22-24, DOI : 10.15740/HAS/ TAJH/13.1/22-24. 